\title{
石炭層メタンの採掘技術・利用目的の現状 と将来展望*
}

緒 方 義 弘 $^{1}$

\section{A Now and Future View of Mining Technologies and Utilizing Purposes of Coal Seam Methane}

by Yoshihiro OGATA ${ }^{\mathrm{a}}$

a. Dr., Direcor-General, Coal Mine Safety Research Center, Hokkaido, National Research Institute of Resoureces and Environment, Shiroishi-ku, Sapporo 003-0029, Japan

The residual reserves of oil and natural gas in the world are able to be mined for only about 40 and 60 years. On the other hand, it is estimated in the long-term future that the thermal nuclear fusion will be utilized to the main energy, and that the atomic power generation and another natural energies will be utilized to the supplementary and local energies.

Coal is reserved over about 11 trillion tons in all the world and about 15 billion tons in Japan. In Hokkaido iland, coal is reserved about 8 billion tons and coal seam methane is reserved about 300 billion $\mathrm{m}^{3}$. But the amount over $90 \%$ of these coal and coal seam methane can not be mined by the now technologies.

The auther evaluates the now mining technologies and utilizing purposes of coal seam methane, and proposes the following items.

(1) From the viewpoints of the available utilization of fosile resources and the groval environments, the coal seam methane have to be utilized to the energy resources of fuel cell etc. and the raw material of chemical products.

(2) In order to mine and utilize the native coal seam methane that are reserved in japanese interior, the inovatie mining and utilizing technologies have to be researched and developed in Japan.

(3) These researches and developments have to be enforced at once by Japanese Gavernment.

KEY WORDS : Coal Seam Methane, Mining Techology, Utilizing Purpose

\section{1. ま え がき}

日本は，近年食料さえもその自給率がカロリー換算で $41 \%$ ま で下がり，自立できる資源は非常に少ないといえる。特にエネル ギー資源は $80 \%$ 以上を輸入に依存しているため, 輸出国の政策 に大きく左右されることになる。

エネルギー資源の中で石油は約 $99.7 \%$ を輸入に依存している し, 天然ガスは国内での生産量が多くなってきてはいるものの, LNG や LPG の輸入に依存している。一方国内で唯一自立の可能 性を持っていたのが石炭であるが，国内での生産は需要量の約 3 $\%$ に過ぎない。すなわち，いずれのエネルギー資源も輸入に依存 しているし，これからも依存することになる。

ところで，石油および天然ガスはその残存埋蔵量が世界的に約 40 数年および 60 数年との予測がある一方, 石油の輸出が主要産 業である産油国は資源の温存を図るための生産調整を行い, これ によって石油価格は将来上昇するといわれている。このため, 残 存埋蔵量および価格の両面から, ポスト石油, ポスト天然ガスと してのエネルギー資源の確保は重要な課題である。また, 石油や 天然ガスはエネルギー資源の原材料としてのみでなく, 各種の化 学製品の原材料として高度に利用されていることから，これらの

* 2000 年 8 月 24 日受付 2001 年 3 月 15 日受理

1. 正会員 博士 (工学) 資源環境技術総合研究所北海道石炭鉱山技術試験 センター 所長

[ 著者連絡先 ] FAX 011-864-3469 (資環研・北海道)

キーワード：石炭層メタン，採掘技術，利用目的，石炭
資源の枯渇は化学製品の原材料の確保にも大きな影響を及ぼすこ とになる。すなわち, エネルギーの代替資源としては, 例えば各 種の自然エネルギーや長期将来には熱核融合等が考えられるが, 化学製品の代替資源は見つかっていないのが現状である。

このような中で, 石炭および石炭層内に大量に包蔵されている メタンガスは世界的に，また国内でも大量の埋蔵量が確認或いは 推定されていることから,これらの開発と利用が日本のみならず, 世界的にもエネルギー資源および化学製品の原材料を確保するた めの大きな鍵を握っているといっても過言ではない。ただし, 石 油, 石炭ともに燃焼による二酸化炭素の大気一の放出や化学製品 の廃棄や焼却が地球温暖化物質や環境モルモンの発生等の原因の 一つであることから, 現状の利用方法では大きな制約を受けるこ とになる。また石炭および石炭層内のメタンガスは埋蔵量が膨大 ではあるが，その大部分は既存技術では採掘不可能な状態で賦存 しているため，革新的な採掘技術の開発，環境への影響が無い製 品への変換技術や処理技術等の利用技術の開発が今後の重要な課 題といえる。

本稿では, 現在主にエネルギー資源として利用されている石油, 天然ガス，石炭等の化石資源の残存埋蔵量 ( 採掘寿命) や利用状 沉等を概観し，特に国内にも大量に埋蔵している石炭層内のメ夕 ンガスを取り上げ，その開発・利用について現状と将来展望につ いて巻末に掲載した各種の報告書や文献等よりまとめ, 私見を述 ベることにする。 


\section{2. 化石資源の残存埋蔵量}

\section{$2 \cdot 1$ 石油}

石油の残存埋蔵量は石油危機が危惧されるたびに40数年間とい う数字が上げられてきた。1998 年 6 月号の「日経サイエンス」に 「しのびよる最後の石油危機」と題した特集記事が掲載された。こ の記事と通産省資源エネルギー庁監修の「資源エネルギー年鑑 (1999〜2000)」とによれば，現時点での石油の採掘寿命として約 43 年間という数字が上げられていて, これまでにいわれてきた数 字とほぼ同じである。

日経サイエンスの記事は米国の 2 人の石油地質学者, C. J. Campbell と J. H. Laherre の論文を翻訳したもの ${ }^{1)}$ であるが，この なかで, 埋蔵量の定義そのものの不明確さ, 公表值の不正確さ等 を指摘しつつ, 既存油田の残存埋蔵量の推定, 未発見埋蔵量の将 来予測, 将来発見される油田の規模予測, 油田発見と石油生産量 の推移等から再評価を行うと, 全世界の石油埋蔵量は約 1 兆 8,000 億バレルであるとしている。そのうちこれまでに約 8,000 億バレ ルが採掘済みで, 未発見の埋蔵量が約 1,500 億バレル, したがっ て現時点で採掘可能な埋蔵量は 8,500 億バレルと予測している。一 方, 世界全体における生産量は約 250 億バレル/年であると推定 されているので, 世界の石油の全残存埋蔵量が約 1 兆バレルであ るとすれば，現状の生産量を維持した場合の石油の採掘寿命は約 40 年となる。

一方, 各産油地域および世界全体の生産量は 2005 年頃をピーク に減少すると予測されており, その結果この生産量がピークを迎 える時期以降には原油価格が上昇すると推定されている。

\section{$2 \cdot 2$ 天然ガス}

1998 年 1 月現在の天然ガスの埋蔵量は世界全体で約 144 兆 $\mathrm{m}^{3}$ とされ, また理論的な埋蔵量は約 300 兆 $\mathrm{m}^{3}$ との推定もある。一 方, 1997 年の生産量が約 2.3 兆 $\mathrm{m}^{3}$ であるから, 採掘寿命は約 63 年となる。しかし, 天然ガスの生産量は増えているが, 消費量も 確実に増えてきている。したがって, 天然ガスの埋蔵量は必ずし も十分ではないといわれている。

我が国における天然ガスの埋蔵量は 1998 年 1 月現在で約 400 億 $\mathrm{m}^{3}$ とされ, また毎年の生産量はこの約 20 年間では全国で $20 \sim 23$ 億 $\mathrm{m}^{3}$ であるので, 天然ガスの寿命は約 20 年となるが, 現実的に は石油と同等の寿命あろうと考えられる。ただし, 天然ガスは石 炭および石油と比べた場合, 硫黄分をほとんど含有していない場

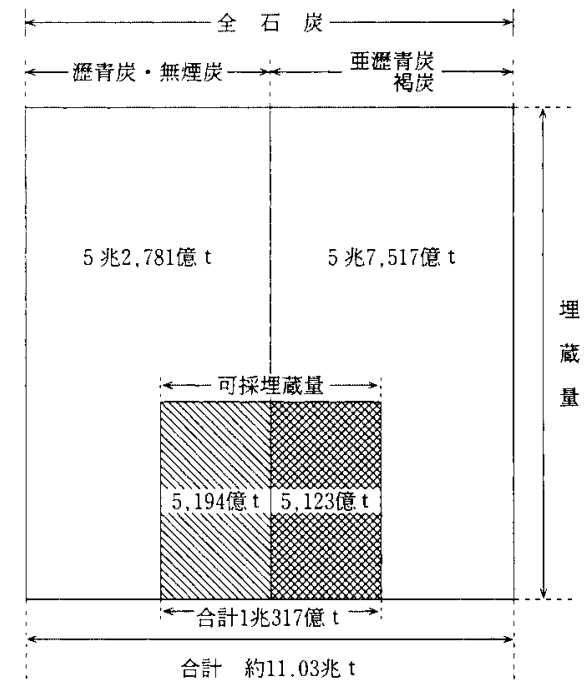

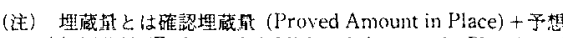

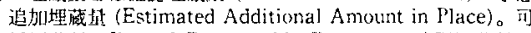

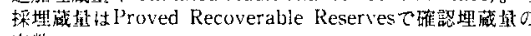
内数。

図 1 世界の石炭の埋蔵量の概念

合が多い上に，メタンが大部分を占めているため，環境への影響 負荷が少ないエネルギー資源とはいえ, このことが使用量の増加, すなわち生産量を増加させ，採掘寿命を短めることになる。また 天然ガスは最近石油と同様に色々な化学製品の原材料としても利 用されている。

\section{$2 \cdot 3$ 石炭}

図 1 は確認埋蔵量と予想 ( 理論的) 埋蔵量を合わせた石炭の全 世界の埋蔵量と, その中で採掘可能な埋蔵量を 2 つの炭質に分け て表している2）。れによれば，究極的な埋蔵量は約 11 兆 $\mathrm{t}$ であ るが，そのうち既存技術および既存技術の延長線上で個体として 採掘可能な埋蔵量は全埋蔵量の約 $10 \%$ に当たる約 1 兆 $\mathrm{t}$ といわれ ている。炭質での内訳は瀝青炭 + 無煙炭と亜瀝青炭 + 褐炭とで は全埋蔵量と採掘可能な埋蔵量ともほぼ同じ量である。なお, 石 炭の特徵は埋蔵量が大きいことの他に, 図 $2^{2)}$ に示すように, 賦 存地域が石油ほどには偏っていないことである。

一方, 全世界の年間採掘量は 1997 年で約 38 億 $\mathrm{t}$ であるので, 採 掘寿命は約 260 年となる。ただし前述のように採掘可能とは何を 指しているか，才なわち坑内採掘が可能な条件をどのように設定

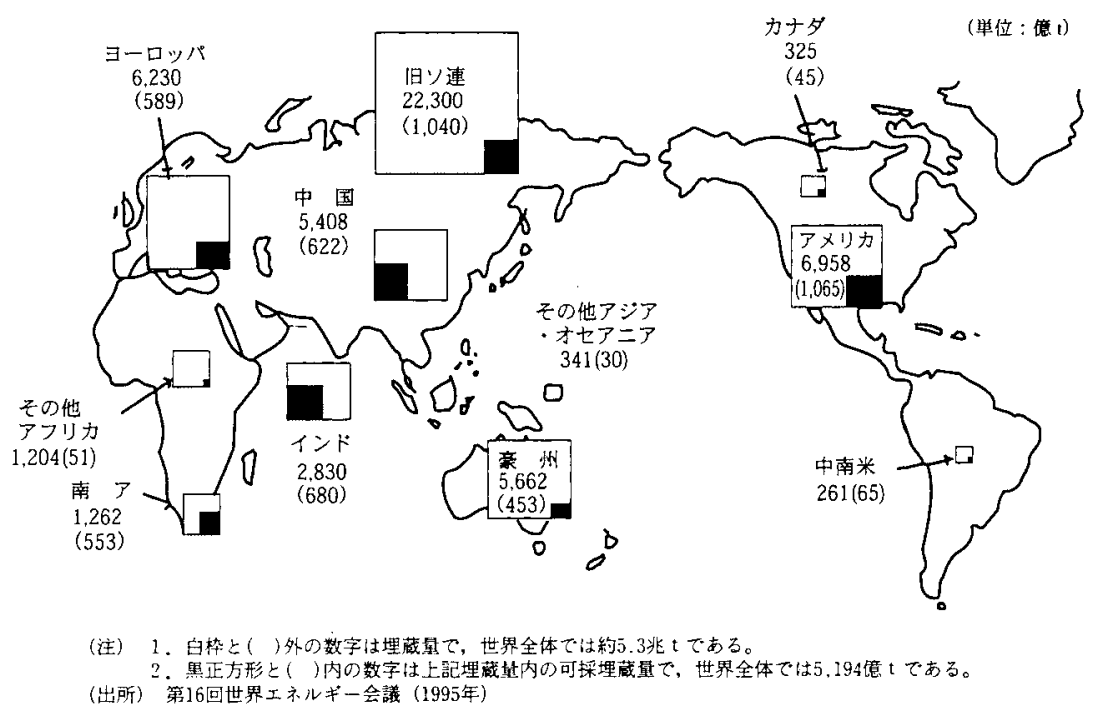

図 2 世界の瀝青炭と無煙炭の埋蔵量 
しているかによって，採掘可能埋蔵量も変わる。また，石油およ び天然ガスの減産に伴う石炭の増産によって採掘寿命が短くなる ことも考えられる。

日本における石炭の埋蔵量は昭和 31 年の埋蔵炭量評価で出され たデータのみしかなく ${ }^{3)}$ ，その後は調查も行われていないが，そ の時点での確定，推定および予想を合計した理論可採埋蔵量は約 200 億 $\mathrm{t}$ である。そのうち採掘された量が約 43 億 $\mathrm{t}$ であるので, 残 存埋蔵量は約 157 億 $\mathrm{t}$ となる。北海道内おける理論可採埋蔵量は 全国の半分以上を占めているので, 残存埋蔵量は約 80 億 $\mathrm{t}$ 以上に なる。これらの数字は昭和 31 年時点での評価であることを考慮す ると, 実際の残存埋蔵量はもつと多いものと思われる。なお，平 成 9 年に北海道通産局で開催された「CMG \& CBM」のワーク

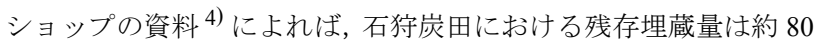
億 $\mathrm{t}$ と評価されていることから, 全北海道ではさらに多くの残存 埋蔵量が期待できる。

\section{3. 新メタン資源}

新メタン資源として非在来型天然ガスが注目されており，その

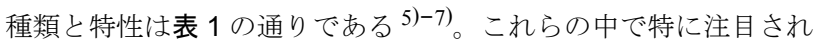
ているのが「深層天然ガス」,「メタンハイドレイト」および「コー ルベッドメタン」の 3 種類である。日本国内では特に「メタン八 イドレイト」が注目されている。またこれらのガスに関して, (財) エネルギー総合工学研究所が調査研究を行い, 平成 4 年にその報 告書 ${ }^{7)}$ を出しているが，その概要は次の通りである。

（1）深層天然ガス：地球深部に賦存するとされ，いろいろな起 源が推測されている。しかし, 実体は未だ把握されていないし, 開発等の対象にもなっていない。

（2）メタンハイドレイト：永久凍土の中にシャーベット状の水 和物の形で存在するメタンガスがよく知られている。日本では相 模湾から四国沖にかけての南海トラフ内の他, 北海道のオホーツ ク海, 奥尻島周辺, 苫小牧沖周辺の大陸棚下に大量に賦存すると され, その埋蔵量は約 2 兆 $\mathrm{m}^{3}$ に達寸るとの説もある。なお, こ れらは物理探査による地質構造上での推測であり, より詳細な物 理探査やボーリング調査等での確認が待たれるところである。

（3）コールベッドメタン: 植物が高温, 高圧で石炭化される段 階で生成されるメタンが石炭の中に包蔵されたガスある。した がって, その埋蔵量は石炭の埋蔵量に比例するが, 石炭の炭化の 程度, 火成岩の貫入の影響, 石炭に対する吸着力が大きい二酸化 炭素の存在等の種々の要因に影響される。国内での石炭の生産は 約 370 万 $\mathrm{t} /$ 年に減ってしまったが, 石炭そのものは未だ大量に賦 存しているので，この純国産の化石資源である石炭およびコール ベッドメタンをいかんに開発し，利用するかが今後の大きな課題

表 1 非在来型天然ガスの種類とその特性

\begin{tabular}{|c|c|c|}
\hline \multicolumn{2}{|c|}{ 類 } & 起源、賦存状態等 \\
\hline コールベッドメタン & $\begin{array}{l}\text { Coal Bed Methane } \\
* \text { Coal Mine Gas }\end{array}$ & 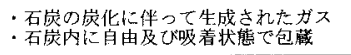 \\
\hline $\begin{array}{l}\text { ガスハイドレイト } \\
\text { (メタンハイドィト) }\end{array}$ & $\begin{array}{l}\text { Hydrate } \\
\text { thane Hydrate }\end{array}$ & 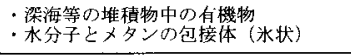 \\
\hline 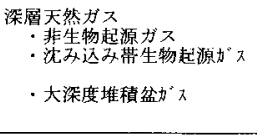 & $\begin{array}{l}\text { Abiogenic Gas } \\
\text { Subducted Organic } \\
\text { Origin Gas } \\
\text { Deep Sedimentary } \\
\text { Basin Gas }\end{array}$ & 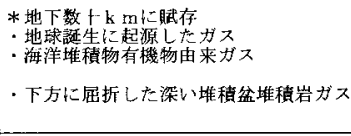 \\
\hline $\begin{array}{c}\text { タイトフォーメイションガス } \\
\text { (タイトサンドガス) }\end{array}$ & $\begin{array}{l}\text { Tight Formation Gas } \\
\text { Tight Sand Gas }\end{array}$ & - 低浸透性白西紀砂岩中に賦存 \\
\hline 高圧水溶性ガス & $\begin{array}{l}\text { Geopressured Zone } \\
\text { Gas }\end{array}$ & 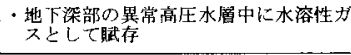 \\
\hline $\begin{array}{l}\text { オイルシェールガス } \\
\text { (オイルサンド) }\end{array}$ & $\begin{array}{l}\text { Oil Shale Gas } \\
\text { Oil Sand Gas }\end{array}$ & · 砂岩や頁岩中に石油として賦存 \\
\hline バイオマスガス & Biomas Gas & ・各種生物の觮敗による発生メタン \\
\hline スワンブガス & Swamp Gas & - 熱带、亜熱帯の湖沼での発生メタン \\
\hline
\end{tabular}

である。なお，コールベッドメタン (CBM:Coal Bed Methane) は石 炭層メタン (CSM:Coal Seam Methane), 石炭層ガス (CSG:Coal Seam Gas), 炭鉱ガス (CMG:Coal Mine Gas) 等のいろいろな呼び方がさ れているが，本稿では石炭層メタン (CSM) と呼ぶことにする。

\section{4. 石炭層メタン}

\section{$4 \cdot 1$ 石炭層メタンの成分}

石炭層メタンは植物が地中で高温, 高圧で石炭に変化する際に 生成され, 石炭の中の割れ目や空隙の中に自由ガスとして, また 石炭表面には化学的吸着ガスとして閉じ込められたガスである。 すなわち石炭層メタンは石炭生成時の副産物である。この石炭層 メタンはメタン, 二酸化炭素, 窒素, ヘリウム等で構成されてい て, 炭質や石炭層の賦存状態等にもよるが，一般にはメタンが 80 〜 $97 \%$ を占めている。例えばオーストラリアやベトナムの一部 では，二酸化炭素の割合が非常に多い石炭層も報告されている。 これは生成時に二酸化炭素が多く生成されたとも考えられるが, 生成後の石炭層が浅いところに賦存しているため, メタンが石炭 層から地表に繋がる亀裂や断層等を通って地表に放出され, 比重 の重い二酸化炭素が残留したこと, 更には火成岩の貫入の影響等 種々の要因が考えられる。国内の石炭層ガスは $93 \sim 97 \%$ \% メ ンであるとの報告がある。

一般に石炭層メタンは石炭の炭化の程度に従って生成量が異な り, 瀝青炭の段階が最も多く発生するといわれている。図 37) は 石炭の炭化の程度 (石炭の質) とメタンの生成量の関係を示して いる。例えば, $1 \mathrm{t}$ の無煙炭が生成された場合, 理論的には約 200

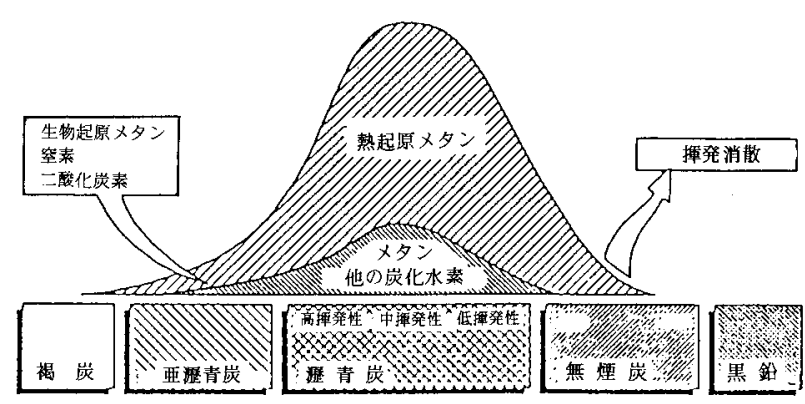

図 3 石炭化とガス発生量の関係

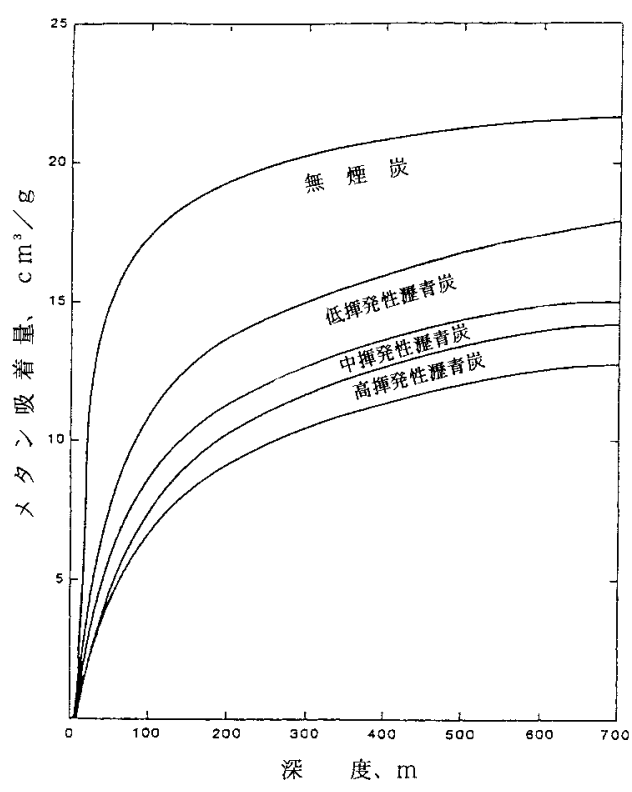

図 4 石炭の賦存深度とガス吸着量の関係 
$\mathrm{m}^{3}$ のメタンが生成されるとの説もある。また，先に述べたように 石炭の賦存状態によっても埋蔵量が異なる。例えば図 47)8) 深度と吸着量との関係を示しているが，メタンの埋蔵量は浅いと ころは前述のような理由で時間の経過に伴って減少し, 一方深い ところでは地圧の増加や地温の上昇等の影響で, 埋蔵量が飽和状 態になるとされている。

\section{$4 \cdot 2$ 石炭層メタンの埋蔵量}

石炭層メタンの埋蔵量は国によってその評価に差があり，現状 では全世界的な評価は難しいため, ここでは国内の埋蔵量につい て述べる。

石炭は国内にも未だ数 10 億 $\mathrm{t}$ から百数 10 億 $\mathrm{t}$ の残存埋蔵量が見 込まれている。この石炭の残存埋蔵量, 採取した石炭試料のメ夕 ン包蔵量 (吸着量), 採炭前に行われるガス抜き時のメタンの濃度 と量, 通気量と通気中のメタン濃度等からメタンの埋蔵量の評価 や推定が行われている。

図 $5^{9)}$ は昭和 56 年度から平成 3 年度までの国内数か所の炭鉱の 出炭 $\mathrm{t}$ 当たりのメタンガス湧出量の推移を示している。これらを 平均化したものが表 $2^{9)}$ である。図 5 からは太平洋炭鉱以外の北 海道の炭鉱のメタンガスは非常に多いことが分かる。例えば空知 炭鉱の場合は $100 \sim 140 \mathrm{~m}^{3} / \mathrm{t}$ の湧出量が報告されている。特に石 狩炭田に位置する炭鉱におけるメタンガスの平均的湧出量は 70 $\mathrm{m}^{3} / \mathrm{t}$ を超えている。これは元々石狩炭田の石炭は石炭化が進んで いること, ガス湧出量には稼行炭層のみならず隣接する炭層から のガスも含まれていること等が大きな要因と推定される。この数 字を用いて石炭層メタンの埋蔵量を推定することが可能である が，ガス湧出量の少ない炭鉱も含めた平均的な值である $37 \mathrm{~m}^{3} / \mathrm{t}$ を用いた場合, 先に示したように石炭の残存埋蔵量が約 80 億 $\mathrm{t}$ と すれば, 北海道全体の石炭層メタンの埋蔵量は約 3,000 億 $\mathrm{m}^{3}$ にな る。ただし, 石炭のメタン包蔵量の評価にはいろいろな要因 ( 石 炭の炭化度, 石炭の賦存状態, 石炭の構造, 石炭層の地質構造特 性等 ) があるため, 湧出メタンガス量のみでの算定には不確実さ を伴うが，いずれにしても大量の石炭層メタンの賦存が見込まれ ることは確かである。

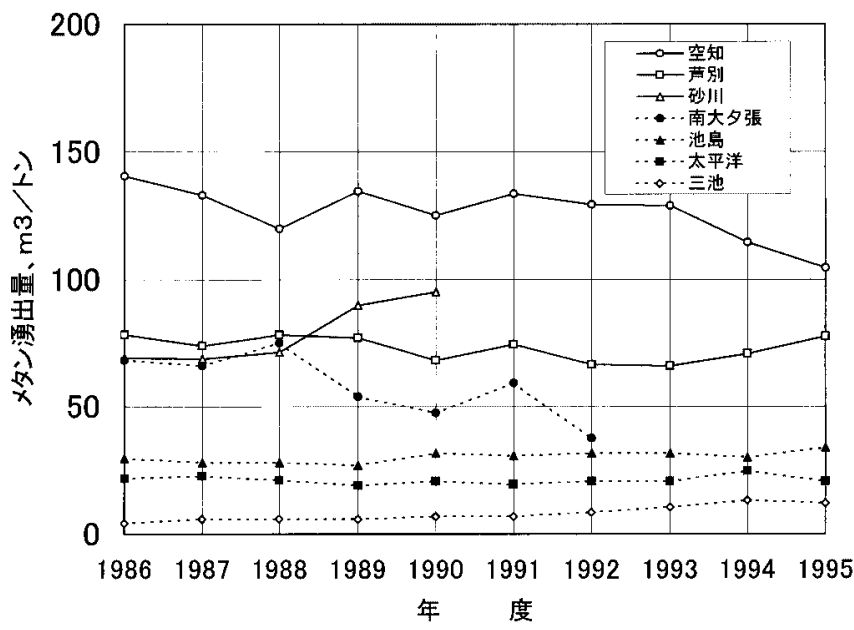

図 5 国内主要炭鉱のメタン湧出量の推移

表 2 生産が安定している期間におけるガス湧出量

\begin{tabular}{|c|c|c|c|c|c|c|c|c|c|c|}
\hline \multirow{3}{*}{ 炭鉱名 } & \multirow{2}{*}{\multicolumn{3}{|c|}{$\begin{array}{l}\text { 生産量 } \\
\text { (千トン/年) }\end{array}$}} & \multicolumn{6}{|c|}{ メ多㯵出量 } & \multirow{3}{*}{$\begin{array}{c}\text { 調查期間 } \\
\text { 年度 }\end{array}$} \\
\hline & & & & \multicolumn{3}{|c|}{ 総湧出量 $(\mathrm{m} 3 / \mathrm{r} \%)$} & \multicolumn{3}{|c|}{ ガス拔き比率 $(\%)$} & \\
\hline & 票大 & 最小 & 平苗 & 最大 & 最小 & 平均 & 最大 & 最小 & 平均 & \\
\hline 空知 & 555 & 450 & 509 & 141 & 119 & 131 & 41 & 36 & 38 & $1986 \sim 1993$ \\
\hline 声別 & 854 & 822 & 836 & 78 & 66 & 75 & 41 & 33 & 38 & $1986 \sim 1993$ \\
\hline 砂川 & 1,075 & 981 & 1,047 & 71 & 68 & 69 & 44 & 40 & 42 & $1986 \sim 1988$ \\
\hline 南大夕張 & 1,160 & 998 & 1,098 & 75 & 66 & 70 & 60 & 57 & 58 & $1986 \sim 1988$ \\
\hline 太平洋 & 2,481 & 2,129 & 2,307 & 26 & 19 & 22 & 36 & 26 & 31 & $1986 \sim 1995$ \\
\hline 三池 & 4,975 & 4,264 & 4.528 & 6 & 4 & 6 & & & & $1986 \sim 1989$ \\
\hline 池島 & 1,530 & 1,408 & 1,448 & 32 & 27 & 29 & & & & $1986 \sim 1990$ \\
\hline
\end{tabular}

\section{$4 \cdot 3$ 石炭層メタンが環境に与える影響}

石炭層ガスは $80 \sim 97 \%$ がメタンで, 残りが窒素, 二酸化炭素, ヘリウム等から構成されている。したがって，単に燃焼に使用し た場合についていえば, 燃焼によって発生する二酸化炭素, $\mathrm{NO}_{x}$ および $\mathrm{SO}_{x}$ の量も極端に少ないため, 天然ガスと同様に環境に優 しいエネルギー資源といえる。ただし, 二酸化炭素, 窒素, 硫黄 等の量が多い石炭層メタンもあり, この場合は, 利用時に問題と なることがある。しかし，一般にはメタン以外の物質が少ないた めに, 石炭層メタンを前処理無しで他の化学製品に直接変換した 場合でも，変換効率が悪くなることはないと考えられる。

\section{$4 \cdot 4$ 石炭層メタンの開発・利用の各国の現状}

$4 \cdot 4 \cdot 1$ 米国の場合 米国における石炭層メタンの開発は 1980 年代後半から本格的に行われ, 1993 年には米国の利用総ガス 量の約 $3 \%$ を占めるに至っている。その後は図 6 ${ }^{10)}$ に示されてい るように徐々に増え，1997 年には約 $5 \%$ までに至っている。

石炭層内に包蔵されるメタンガスは1930年代から注目されてい たが, 開発技術およびコストの関係から実際の取り組みは 1970 年 代に入ってからである。したがって, 当初は坑内保安上, ガス抜 きの効率的な実施が主であったが，その後廃坑跡からのメタン回 収と利用に移行している。1970 年代には石炭層メタンの埋蔵量の 調查が経済性を中心として検討され，1980 年代に入ってからは, 有望な炭田を対象とした採掘技術の開発と実際の採掘による評価 が行われてきた。

米国の炭田は大きく四つの地域に分けられ，そのうち石炭層义 タンの開発の対象としては東部アパラチア炭田最南端のブラッ ク・ウオリア (Black Warrior) および西部ロッキー山脈炭田最南端 のサン・ファン (San Juan) の 2 か所の石炭盆地が選ばれ，採掘が 開始された。この 2 か所の石炭盆地における石炭層メタンの包蔵 特性および採掘実績の概要は表 $3^{11)}$ の通りである。

米国で石炭層メタンの開発の対象になっている石炭層は飽和水 または地下水で飽和されているため, まず水抜きを行う必要があ り, その技術の開発も重要視されている。特に前記の 2 つの石炭 盆地の場合, 実際にメタンガスを採掘できるまでには, 1 年間以

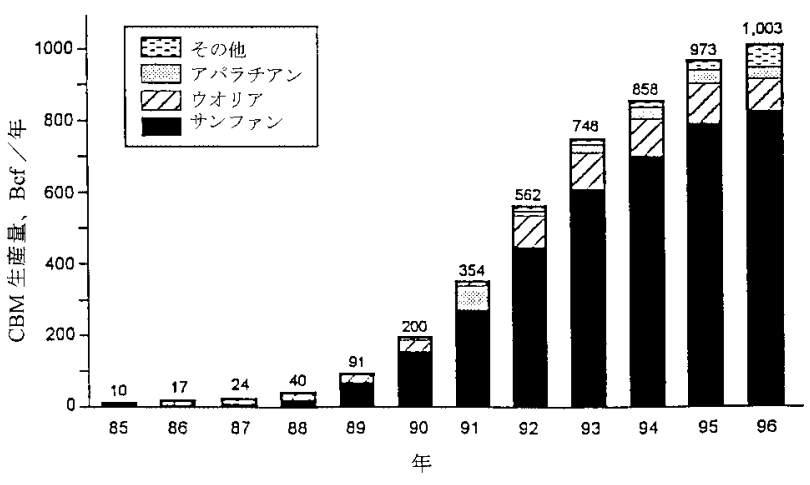

図 6 米国における石炭層メタン生産量の推移

表 3 米国の 2 か所の石炭層メタンの採掘対象堆積盆地の特性

\begin{tabular}{|c|c|c|}
\hline 項 目 & サンファン堆矰盆地 & エ゙ラック・ウオリア堆積盆地 \\
\hline 栗度 & $\sim 1200 \mathrm{~m}$ & \\
\hline 積 & $20,000 \mathrm{~km}$ & $46,000 \mathrm{~km}^{3}$ \\
\hline & 平均 $2 \sim 5 \mathrm{~m}$ & \\
\hline 度 & 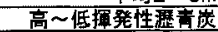 & 高 低揮発性沜青宸 \\
\hline & $10 \sim 16 \mathrm{~m} 3 / \mathrm{t})(1$ & $5 \sim 15 \mathrm{~m} 3 / \mathrm{F},(300 \mathrm{~m})$ \\
\hline 源量 & 1兆4200億 $\mathrm{m} 3$ & 5700億甶3 \\
\hline 坑茾数 & 1368本 (1991/12) & 2737本(1991/12) \\
\hline 坑井平均深度 & $1000 \mathrm{~m}$ & $460 \mathrm{~m}$ \\
\hline 平均生痖量/坑 & $15000 \mathrm{~m} 3 /$ 日 $(1992 / 10)$ & $2000 \mathrm{~m} 3 / \mathrm{B}(1992 / 1 \mathrm{c}$ \\
\hline 年間生産量 & 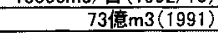 & 19億的3 (1991) \\
\hline
\end{tabular}


上飽和水の汲み上げを行うことが必要となっている。

なお，米国において石炭層ガスの商業化生産が成功したのは国 による税制上の特別な優遇やエネルギー省鉱山局等の政府機関が 全面的に支援したこと，既設のガスパイプラインへの接続が容易 であったこと等が上げられる。

$4 \cdot 4 \cdot 2$ オーストラリアの場合 オーストラリアの場合 は，日本と同様に坑内保安に関連したガス抜き技術の開発が主な 目的であった。特に深度が浅い場合には, 地表からのボーリング によってガス抜きが行われ，そのための技術開発や抜き取ったメ タンを自家発電や燃料に利用した経緯がある。

石炭層メタンの開発が始められた当初は，採掘跡空洞からのガ スの採掘を対象とした研究が行われたが, その後 1970 年代後半に なってからは, 図 $7^{11)}$ に示すような 2 つ石炭盆地を中心にかな り広い範囲の炭田を対象として, 商業生産を念頭に置いた開発が 始められた。この場合, 石油開発会社が中心となって探查が進め られたが，有望な炭田すなわち商業化できる炭田を発見するには 至らなかった。

しかし, 1980 年代後半の米国での石炭層メタンの採掘実験の成 功の報告に刺激されて, 探査活動が再開され, また有望な石炭層 の発見もあり, 生産設備を備えた試験採掘が行われ始めた。ただ し, この場合においても資源量の問題から試験段階の域を脱し得 なかった。更にその後, 1990 年代に入ってから 3 か所の石炭盆地 でパイロット規模での開発が進められ，そのうち2 か所は商業生 産に発展したが，もう 1 か所は未だ開発の段階である。これらの 3 か所の概要を表 $4^{12)}$ に示した。

オーストラリアの場合は, 米国で行われていた税制上の優遇処

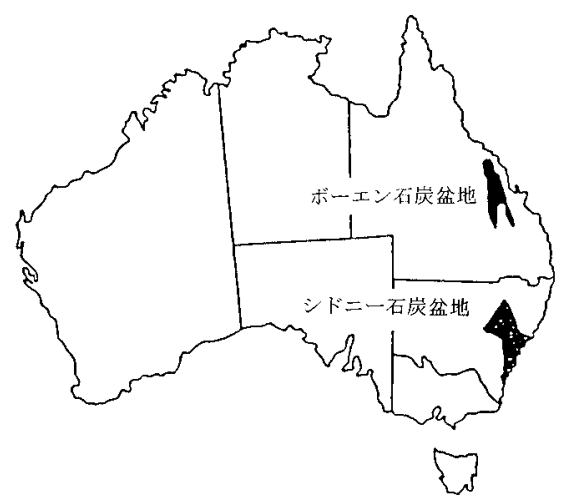

図 7 オーストラリアにおける石炭層メタンの開発対象炭田

表 4 オーストラリアにおける石炭層メタンの開発状況

\begin{tabular}{|c|c|c|c|}
\hline 能田地域 & Dawson Valley & Fairview & Peat \\
\hline 石炭永地 & Bowen Basin & $\begin{array}{l}\text { Bowen Basin } \\
\text { 南西部 }\end{array}$ & $\begin{array}{l}\text { Bowen Basin } \\
\text { 南西部 }\end{array}$ \\
\hline 石谈風 & Baralaba 夾炭層 & Bandanna 累層 & Baralaba 夾炭層 \\
\hline 石炭䚙㕌さ & $\begin{array}{l}\text { 総厚 } 11 \sim 20 \mathrm{~m} \\
(\text { 各層 } 1 \sim 5 \mathrm{~m})\end{array}$ & & (各層 $5 \sim 11 \mathrm{~m}$ \\
\hline \multicolumn{4}{|l|}{ ガス含有率 } \\
\hline 犺牛数 & 35 本 & 24 本 & 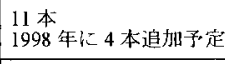 \\
\hline 生座開始 & 1996 年 & 1997 年 & 評価中 \\
\hline 生産覃 & & $\begin{array}{l}7,000 \mathrm{~m} 3 / \mathrm{d} / \text { 本 } \\
41 \mathrm{Mm} 3(1996 \sim \\
1997 \text { 年) }\end{array}$ & \\
\hline 利用同的 & $\begin{array}{l}\text { 既存パイプライ } \\
\text { 经接続 } \\
\end{array}$ & & \\
\hline 備考 & 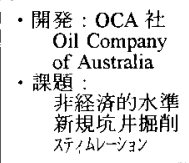 & $\begin{array}{l}\text { 關発 : Tri-Star } \\
\text { Petroleum 社 }\end{array}$ & 開発：OCA 社 \\
\hline
\end{tabular}

置や政府機関の支援等はほとんどなく, 当初から一般企業 (特に石 油開発会社）が自己資本で開発を行っている。なお，CSIRO 等の 政府および州機関の研究所が技術面での支援を行っている。

オーストラリアに関して特記すべき事項は, 三菱ガス化学 (株) が 1991 から 1992 年にかけてメタノールの原材料として石炭層メ タンの開発を Bowen Basin 北部で試みたことである。この場合 10 本の調査坑井が掘削されたが, 粘土質鉱物等によって空隙等が充 填されていて, 浸透率が非常に低いため, 生産は断念された。し かし, 表 4 に見られるようにオーストラリアで商業生産が行われ ているのは Bowen Basinの南西部であることから, もし三菱ガス 化学(株) が Bowen Basinの南西部を対象としていたとすれば, 商 業生産ができたことは容易に想像できる。

$4 \cdot 4 \cdot 3$ 中国の場合 中国における石炭層メタンの全埋蔵 量は深さが $2,000 \mathrm{~m}$ 以浅では約 35 兆 $\mathrm{m}^{3}{ }^{13}$, 主要炭田では約 14 兆 $\mathrm{m}^{3}$ 14) と推定されている。一方石炭の採掘に伴って湧出している 石炭層メタンは露天掘りを含めた約 680 の炭鉱全体で年間約 49 億 $\mathrm{m}^{3}$ (1994 年, 出炭量約 51 億 $\mathrm{t} /$ 年), このうち何らかの形で利用さ れている石炭層メタンは年間約 4 億 $\mathrm{m}^{3}$, 寸なわち年間約 45 億 $\mathrm{m}^{3}$ が大気中に放出されていることになる。

中国の場合, 主要炭鉱の大部分はメタンが高圧の状態にあるか あるいは突出しやすい状態にあるといわれていることから, 石炭 層メタンの採掘は基本的には炭鉱の安全性の向上と生産性条件の 改善のためのガス抜きが主目的である。このため, 1950 年代から 採掘対象の石炭層から事前に地上および坑内からのボーリングに よるガス抜きを実施してきている。また採掘跡からも同様に地上 からのボーリングによるガス抜きを行ってきている。

中国においては，ガス抜きで採掘されたメタンガスの回収と利 用は各地区の鉱務局が実施していて，代表的な地域で行われてい る採掘・回収の方法およびその量, 利用方法とその量を表 $5^{13)}$ に 示した。

しかし, 近年は石炭産業の戦略として石炭層メタンの開発を目 指し，1990 年代に入ってからは石炭層メタンを本格的に採掘寸る プロジェクトが, 中国政府 (高圧ガス鉱務局, 媒炭工業部, 中国石 油天然ガス公社等) が中心となって図 $8^{13)}$ に示す 21 か所で進めら れている。このプロジェクトにおいては，1990～ 1994 年にかけ て資源量評価と生産のためのボーリングが 39 本掘削されている が，1995 年現在で生産されているの下記の通りである。

(1) Xuhai 炭田: 採掘跡から $500 \sim 1,000 \mathrm{~m}^{3} /$ 日

(2) Lubei 炭田: 未採掘区域から $6,000 \mathrm{~m}^{3} /$ 日

（3）松遼炭田：採掘跡および事前ガス抜きから 21,600 $\mathrm{m}^{3} /$ 日

（4）泌水炭田: 未採掘区域加 3,000 5,000 $\mathrm{m}^{3} /$ 日（米国企業 との共同で実施）

上記のほかに, 古城子褐炭炭田では米国との共同で水圧破砕に

表 5 中国におけるガス抜きで回収されたガスの利用状況

\begin{tabular}{|c|c|c|c|c|c|}
\hline \multirow{2}{*}{ 地域名 } & \multicolumn{2}{|c|}{ 採掘 - 回収 } & \multicolumn{2}{|c|}{ 利用 } & \multirow{2}{*}{$\begin{array}{c}\text { メタン整愿 } \\
\%\end{array}$} \\
\hline & 少法 & 量、 $\mathrm{m}^{3}$ & 目的 & 量、\% & \\
\hline 樭順 & ガ不抜き & 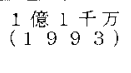 & $\begin{array}{l}\text { 蒙庭 } \\
\text { 华裳】 } \\
\text { 需 }\end{array}$ & $\begin{array}{ll}7 & 5 \\
2 & 0 \\
& 5\end{array}$ & $33 \sim 58$ \\
\hline 鉄法 & ガ不抜き & $\left.\begin{array}{lllll}1 & 6 & 0 & 0 & 5 \\
(1 & 9 & 9 & 4\end{array}\right)$ & 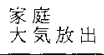 & $\begin{array}{ll}2 & 5 \\
7 & 5 \\
\end{array}$ & $30 \sim 90$ \\
\hline 鹤壁 & ガ不拻き & $\left(\begin{array}{r}650 \pi \\
1994\end{array}\right)$ & 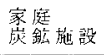 & $\begin{array}{ll}7 & 8 \\
1 & 3\end{array}$ & $30 \sim 40$ \\
\hline 開梁 & ガス拔き & $\left(\begin{array}{cccc}9 & 0 & 0 & \pi \\
1 & 9 & 9 & 2\end{array}\right)$ & 蒙庭 & $\Leftrightarrow 0$ & $30 \sim 40$ \\
\hline 陽泉 & ガス拻き & $\left(\begin{array}{lllll}9 & 0 & 0 & 0 & \pi \\
1 & 9 & 9 & 3\end{array}\right)$ & 家庭 & 全量 & $?$ \\
\hline 松藻 & ガス抜き & $\left(\begin{array}{lllll}6 & 0 & 0 & 0 & 7 \\
1 & 9 & 9 & 0\end{array}\right)$ & $\begin{array}{l}\text { 家庭 } \\
\text { 齿施設 } \\
\text { 工業 }\end{array}$ & $\begin{array}{ll}3 & 5 \\
4 & 7 \\
1 & 3\end{array}$ & $100 ?$ \\
\hline
\end{tabular}




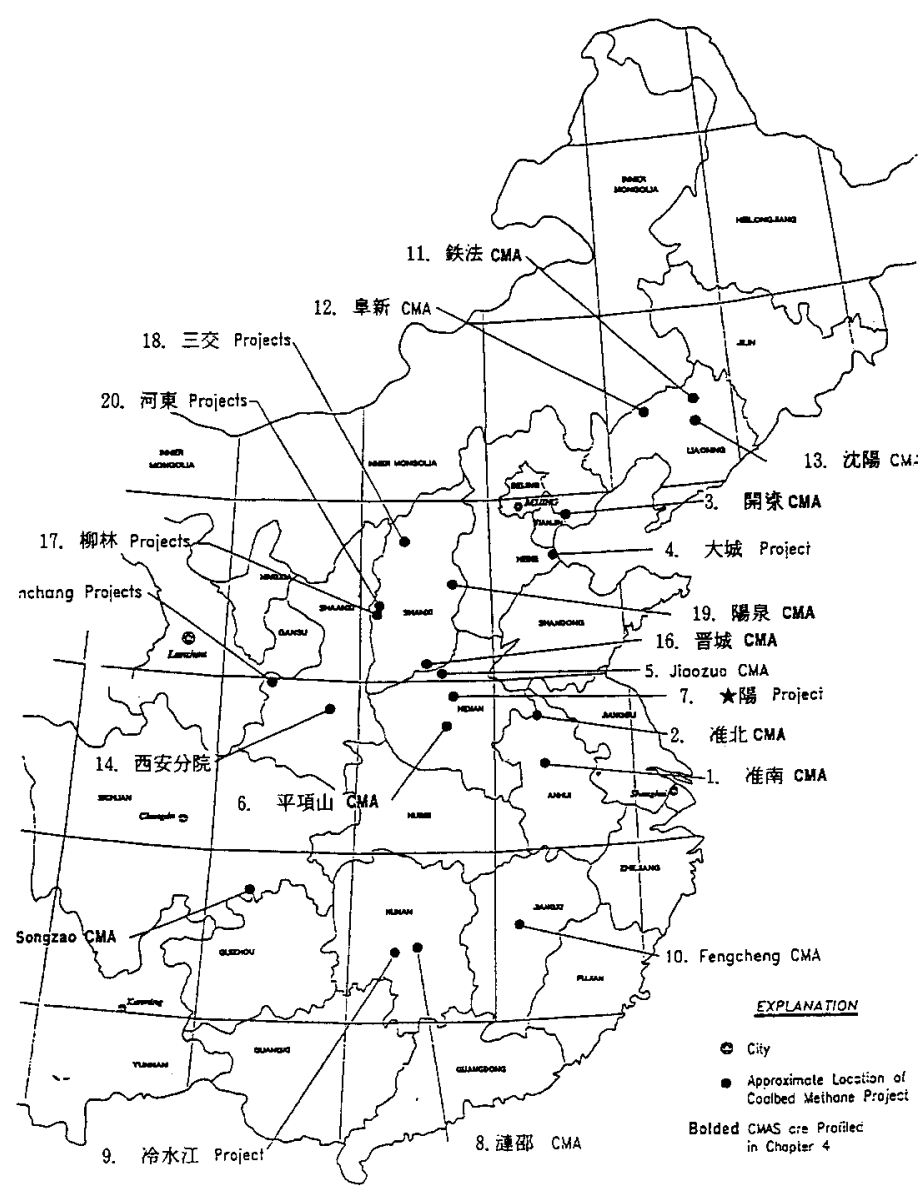

図 8 中国における石炭層メタンの開発プロジェクト地域

よる坑井刺激 (スティムレーション ) を行い, $1,800 \mathrm{~m}^{3} /$ 日の生産 実績がある。

以上から推察すると, 中国の場合は石炭層メタンをエネルギー 資源として採掘, 利用するプロジェクトも推進されているが, 既 存の炭鉱から大量に大気に放出されている石炭層メタンをいかに 回収し，利用するかが地球環境およびエネルギ一資源の有効利用 の両面から重要な課題であるといえる。

$4 \cdot 4 \cdot 4$ 日本の場合日本の場合は, 採掘前のガス抜き効 果を高めるためのボーリング技術や水圧破砕法の検討, また室内 実験, シミュレーション解析, 現場実験等が行われてきたが, 石 炭層メタンそのものの開発は対象とされなかった。これ は国内の石炭層メタンは埋蔵量(資源量)および経済環境 の上から有望ではないとの見方が強く，大部分の専門家 は海外での開発に期待を寄せていることである。すなわ ち,このことが現在国内での研究開発を阻害している一つ の大きな要因になっている。

資源環境技術総合研究所では, (財) エネルギー総合工学 研究所の調査報告によれば国内においても大量の石炭層 メタンが賦存する可能性が高いこと，また次世代のエネ ルギー資源としてだけでなく各種の化学製品の原材料と しての役割が大きいこと等を踏まえて, 平成 6 年度から 平成 10 年度までの 5 年間, 工業技術院ニューサンシャイ ン計画 (NSS) プロジェクト「コールベッドメタンの採取 利用技術」として研究が行われた。図 9 はこのプロジェ クトにおける研究開発の概念を表している。このプロ ジェクトでは(1)採取技術, (2)メタンの選択回収プロセス,
(3)化学変換プロセスの3 項目についての研究が行われた。 しかし予算上の制約等もあり, 基礎的な部分およびプロ セスの研究に限られた。例えば採取技術に関しては, 国 内 2 炭鉱の石炭の基礎物性 (強度, 透気係数) 試験とそ のデータによる採掘シミュレーションの検討であった。

また平成 9 年度から 10 年度にかけて, 資源エネルギー 庁石油部開発課および石油公団の委託で NEDO, JCOAL が北海道を対象にした石炭層メタンの資源量調査を既存 の資料を元に実施し, 成果は平成 10 年 9 月に北海道通産 局で開催されたワークショップで報告された ${ }^{4)}$ 。一方, JCOAL が資源エネルギー庁石炭新エネルギー部石炭課の 事業 (NEDO の委託事業) で開発途上国, 特に中国におけ る炭鈗ガスの回収・利用の技術援助を行う形でかかわっ てきている。しかし，これは地球環境への取り組みの一 環としての対応であり, 将来の化石資源の確保との視点 とはかなり異なっている。なお，JCOAL は旧石炭技術研 究所時代から国内の石炭層メタンに関する調查や実験 ・ 試験および米国を中心とした海外の石炭層メタンの採 掘・利用技術に関わる調查研究を継続して実施してきて いる。

$4 \cdot 4 \cdot 5$ その他の国の場合 その他の国の場合は 石炭層メタンの開発を主目的としたのもではなく，炭鉱 保安におけるガス抜き技術の開発としての研究である。 しかし，英国等で行われているガス抜き技術およびそれ に関連した石炭層内でのガスの流れの数值モデル化の 研究等 ${ }^{15) 16)}$ は石炭層メタンの効率的な採掘技術 (採掘シ ステム) の開発や, 英国やフランス等の古い産炭地を有 するところにおける閉山炭鉱でのメタンガスの回収に大 いに役立つものと考えられる。

\section{5. 石炭層メタンの採掘技術}

\section{$5 \cdot 1$ 石炭層メタンの採掘技術の現状}

石炭層メタンの開発を商業化したのは米国およびオーストラリ アであることから，両国での開発段階から現在までの技術的な経 緯を中心に採掘技術の現状を概観する。

石炭層メタンの採掘に当たっては, 大きくは下記の 3 つの項目 についての調査, 研究や技術開発等が必要である。

(1) 石炭および石炭層の物性や地質学的特性等の評価

(2) 最適採掘システムの選定

(3) 採掘の経済性評価

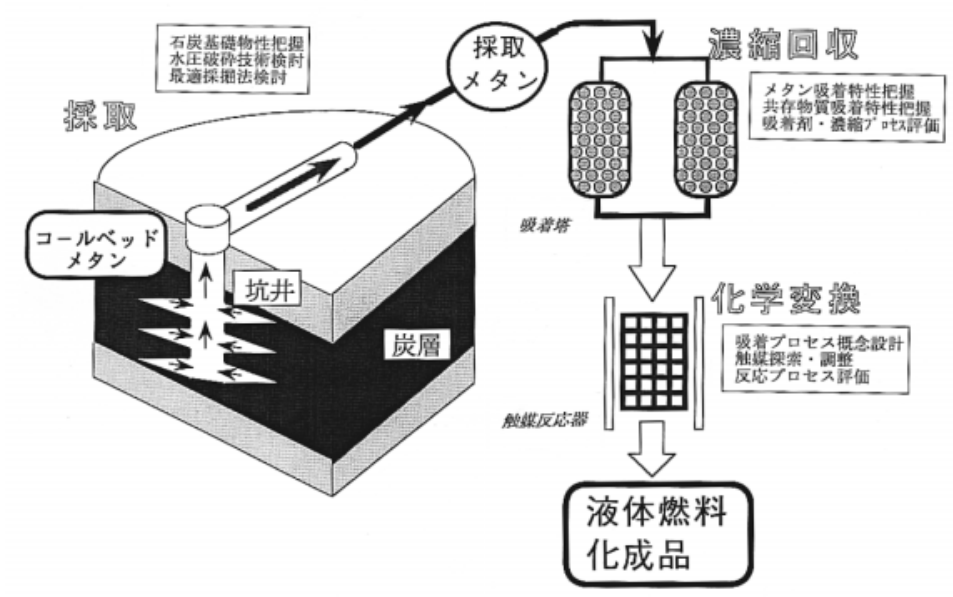

図 9 資環研における石炭層メタンの採掘・利用技術の研究開発概念 
なおここでは(1)と(2)についてのみに触れることにする。

\section{$5 \cdot 1 \cdot 1$ 石炭および石炭層の物性や地質学的特性等の評価}

まず，メタンを包蔵する石炭層全体の貯留形態やメタンの埋蔵量 等が評価される。特に未開発の石炭層の場合は，これらを評価す る既存の資料が少ないため, 物理探査やボーリング調査, 採取し たコアによる室内試験等によって総合的な評価が行われる。ここ での試験や評価が正しく行われないと, 埋蔵量を正確に評価でき ないだけでなく, (2)の最適採掘システムの選定や(3)の採掘の経済 性評価等も正確に行えないことになる。すなわち，この最初の段 階における各種の評価が石炭層メタン開発の成功の大きな鍵を 握っているともいえる。

検討や評価の対象とされる項目は次の通りである。

(1) 石炭の埋蔵量

（2）石炭層の地質構造特性 : 深度, 傾斜, 炭丈, 不連続性, 地 圧，浸透水 (飽和水) 等

(3) 石炭の化学的特性 : 炭化度, メタン吸着度 (包蔵量)

(4) 石炭の物理的特性 : 空隙率, 浸透率等

これらの情報を基にして, 石炭層メタンの埋蔵量, 石炭, 砂岩, 頁岩で構成される地層形態等を評価し，数值モデルを用いたシ ミュレーション等を含めて, 最適な採掘技術やシステムが決めら れる。例えば，米国では石炭層メタンの貯留層の評価に表 $6^{17)}$ に 示すような項目が用いられている。

\section{$5 \cdot 1 \cdot 2$ 最適採掘システムの選定}

(1) 坑井掘削技術 メタンの採掘を効率的に行うには, 坑井 の掘削が重要な要素の一つである。米国においては, 当初坑井は 石炭層内を層に沿って掘削（沿層ボーリング）するのが最良であ るとの観点から，地表から垂直に掘削した坑井をターボドリル等 を用いて途中から曲げ，最終的には石炭層内を掘進する方式が検 討された。しかし，実用化には至らなかった。これは石炭層が多 数の亀裂 (割れ目) 等が入った複雑な構造をしている一方, 軟弱 な層や擾乱帯等が影響して, 切削や掘削制御が難しいことが要因 として上げられる。このため, 坑井は地上から垂直に掘削し, 石 炭層を貫くような方式が取られ, 以降この方式が用いられている。

坑井の掘削は一般にケーシングを入れながら, 地上から石炭層 に直交するように行われるが，その際石炭層の部分にケーシング を入れるか否かによって, 図 1017) のように 3 種類の方法が取ら れている。

(a) 採取対象石炭層部分が裸坑の場合

(b) 坑井全長にケーシングを入れ, 石炭層の部分 のケーシングには切れ目を入れる場合

（c）（a）と（b）の混成であり，採掘対象の最下部の 石炭層部分にはケーシングを入れない場合 いずれを選択するかは採掘の対象となる石炭層, 地

表 6 米国で用いられている石炭層メタンの 貯留層評価のための主要要因

\begin{tabular}{|c|c|c|}
\hline & ファクター & 評価のためのデータ取得源 \\
\hline 1 & 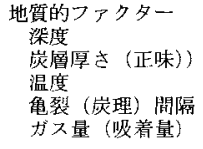 & 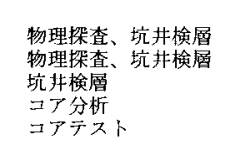 \\
\hline 2 & 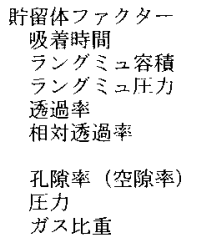 & $\begin{array}{l}\text { コアテスト } \\
\text { コアテスト } \\
\text { コアテスト } \\
\text { 坑井テスト } \\
\text { ヒストリーマッピンク } \\
\quad \text { (履歴照命) } \\
\text { 坑井テスト } \\
\text { 坑井テスト } \\
\text { サンプルガス分析 }\end{array}$ \\
\hline
\end{tabular}

下水 (包蔵水)の影響, 坑井の安定性等の種々の要因や条件を考慮 して決められている。

(2) スティムレーション (坑井刺激) 技術石炭層メタンの 最適採掘システムの選定に当たって重要な課題は, 石炭層メタン を包蔵している石炭および石炭層内におけるメタンガスの流動特 性の評価にある。基本的な流動パターンは図 1117) のような過程が 一般的なモデルとしてよく用いられている。特に石炭の中の炭理 や微細孔, 石炭層内の天然亀裂等は石炭層メタンの流動性や流動 範囲を左右する透過性 ( 透気性, 透水性) と密接に関連している。 しかし図11のような過程でメタンガスが坑井まで流動する範囲は 極く限られるため, この流動性を高め, 流動範囲を拡大寸る必要 がある。

一般には透過性を左右する炭理や微細孔，石炭層内の天然亀裂 等は

(1) その量が十分にあり，坑井まで繋がっている

(2) その量が十分にあっても，坑井まで繋がっていない

(3) その量は少ないが，坑井までは繋がっている

(4) その量が少なく, 坑井まで繋がっていない

の 4 つの状態が考えられる。これらの状態のうち, 石油や天然ガ スのように自噴する(1)の例は少なく, 通常石炭の空隙や石炭層の 亀裂等は地圧によって閉じた状態になっている場合が多いため, (2)，(3)，(4)の場合を想定す心゙きであろう。したがって石炭層メタ ンが流動しや寸いように, 石炭層内にガス道を作成することがも う一つの大きな技術的な課題である。これをスティムレーション ( 坑井刺激) と呼んでいる。

スティムレーションの方法としては水圧破砕法が一般に用いら れている。これは石炭層の部分の坑井の一部をパッカーと呼ばれ ているゴム製の栓で仕切り, このゴム栓で仕切られた区間に高圧 の水を押し込むことによって, 石炭層内に亀裂 (割れ目) を入れ, この亀裂をガス道にする方式である。しかし，このような人工の 亀裂は破砕作業の終了後に水圧を下げると, 亀裂が閉じるため, 砂やプロパントと呼ばれている材料を開いた亀裂の中に押し込ん で, 水圧を下げても亀裂が閉じないような工夫を行う必要がある。 これをプロッピング(支持) と呼び, プロッピングに用いられる砂 やプロパント等の材料をプロッピング材と呼んでいる。

図 12 ${ }^{18)}$ は, 米国の Warrior 炭田における水圧破砕時の時間の経

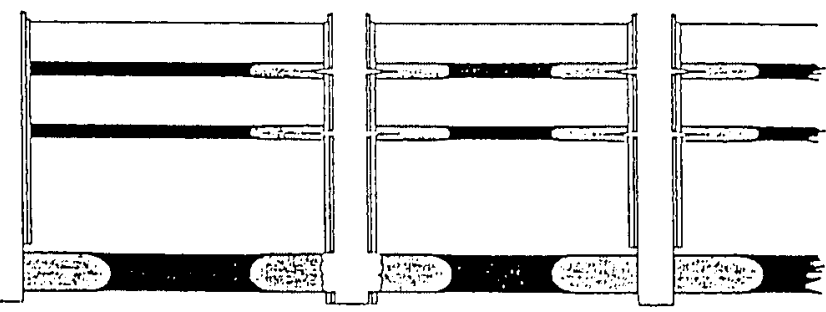

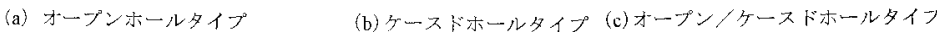
図 10 掘削後の坑井仕上げの方法

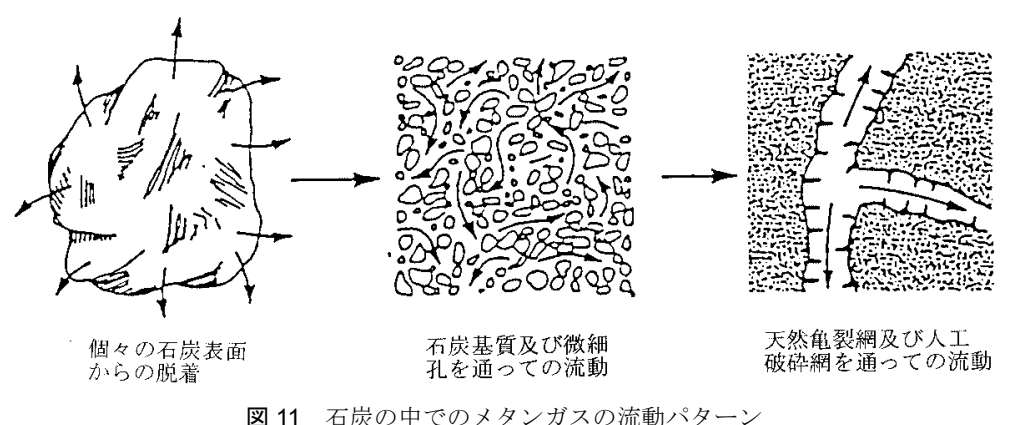

図 11 石炭の中でのメタンガスの流動パターン 


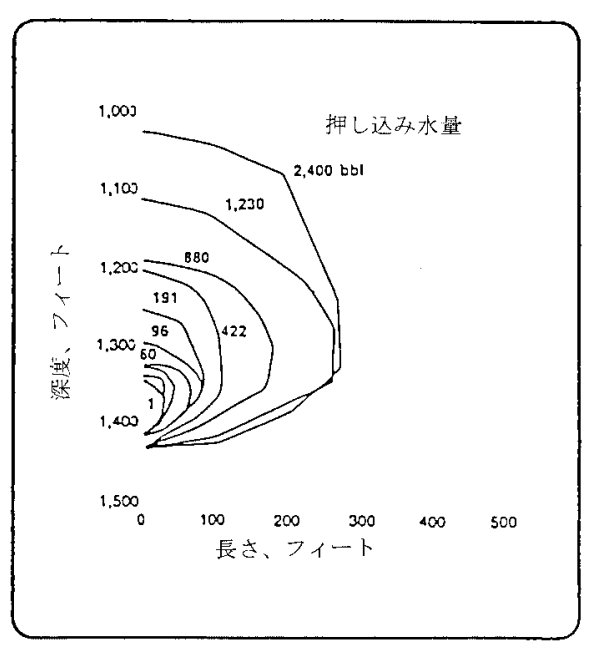

図 12 水圧破砕による破砕面の広がりの経時変化

過(水の押し込み量の変化) に伴う破砕面の広がり状況を示してい る。この場合, 破砕が深度約 $1,400 \mathrm{ft}$ の坑井周辺で発生した後, そ の破砕面が時間の経過に伴って右上方に広がっていることが分か る。破砕面は水平方向に約 $300 \mathrm{ft}$ ( 約 $100 \mathrm{~m}$ ), 垂直方向に約 400 $\mathrm{ft}$ (約 $130 \mathrm{~m}$ ) 広がっている。なお作用している地圧の大きさが方 向によって扁平でなければ, 水圧によって発生する破砕は通常坑 井を中心にして対称的になるため, この破砕面は水平方向に約 600 $\mathrm{ft}$ (約 $200 \mathrm{~m}$ ), 垂直方向に約 $400 \mathrm{ft}$ (約 $130 \mathrm{~m}$ ) の範囲で, 蝶々が 羽を開いたような形で広がる。これを表した例が図 13 ${ }^{19)}$ であり, これは Warrior 炭田の Black Creek で行われた水圧破砕における最 終破砕形態(推定) を示している。しかし水圧破砕による亀裂の作 成は対象となる地層や石炭層等の特性および地圧等に大きく支配 されるため, 設計通りの亀裂を作成するのは困難である。例えば 図 13 の場合は二次元の縦断面図であるため, 三次元的な広がりは 不明であるが, 破砕面は垂直縦方向に広がっていると推測される。 寸なわち, この場合は図面の上下方向からの地圧が最大で, 図面 に直交する方向からの地圧が最小であることが推測できる。この ような破砕形態が形成されるのは, 地圧の大きさが作用する方向 によって大きく異なる場合であり, その差が小さい場合は破砕形 態が石炭層および上下岩盤の特性, 特にクリークと呼ばれている 石炭層内の亀裂や節理 (炭理) 等の大きさや方向に支配される。こ のような水圧破砕による破砕形態のいくつかのパターンを模擬的 に示したのが図 1420) である。図 14 の破砕形態のパターンを地圧 のみとの関係で説明すると, (A) のパターンは垂直方向の地圧が 最小で, 水平方向の地圧が最大, (B) のパターンは図面に直行する

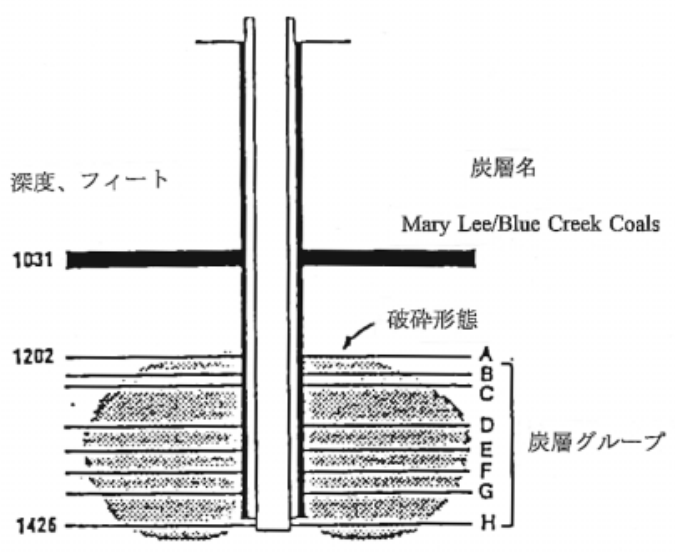

図 13 水圧破砝による最終破砕面 (推定)

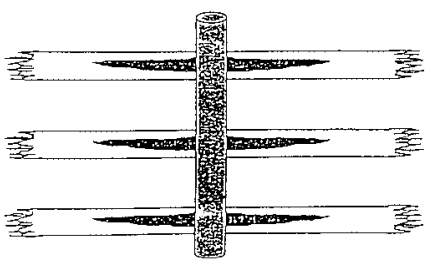

（A）炭層内に発生した水平破砕面

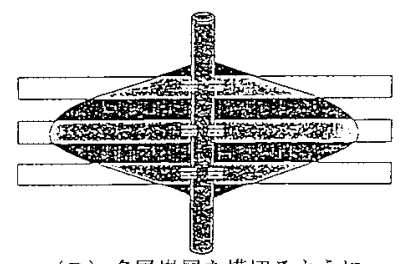

(B) 多層炭層を横切るように

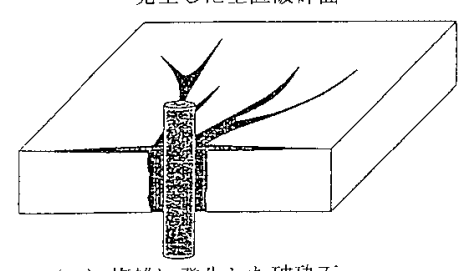

(C) 複雜に発生した破砕面

図 14 水圧破砕による破砕面の形成様式の概念

方向の地圧が最小で, 垂直方向の地圧が最大, (C) のパターンは地 圧の大きさの方向による差が小さい場合をそれぞれ示している。 多分 (B) のパターンが図 13 に相当している。すなわち, スティム レーションは前述の地質構造や石炭の物理特性等の評価, 坑井掘 削技術等と併せて総合的に設計することが必要である。

スティムレーションには一般に水圧破砕が採用されているが, オーストラリアにおいてはその他特殊なスティムレーション技術 の研究開発も行われている。例えば坑井周辺の石炭層部分に何ら の方法で空洞を作成し，この空洞を地圧で押し潰すことによって 周辺の石炭層内に亀裂を発生, 伸長させ, 透過率を大きくする方 法である。この空洞を作成する方法をキャビティ法と呼んでいる。 この空洞の作成方法としては,

(1) 塩酸等で坑井周辺の石炭を溶か寸方法

(2) 石炭層の部分のみを拡孔掘削や水噴流掘削等で広げる方法

(3) 坑井内に高圧 ( 水圧または空気圧) を加えた後, 急激に減 圧する方法

等が研究され, また現場での実験も行われている。図 15 ${ }^{13)}$ は石 炭層部分に穴あきライナーを用いて, (3)の方法で空洞 (キャビ ティー)を作成した状態を模擬的に示している。また図 16 ${ }^{13)}$ は空 洞が作成された後, 時間の経過に伴う空洞周辺の岩盤層および石 炭層の変形や応力状態の変化を示している。

\section{$5 \cdot 2$ 石炭層メタンの採掘技術の長期展望}

$5 \cdot 1$ で石炭層メタンの採掘技術の現状の概要を示したが, 地上 からの坑井の掘削と水圧破砕によるスティムレーションとを組み 合わせた採掘システムが基本になっている。ただしスティムレー ションに関して水圧破砕以外の技術の研究開発がオーストラリア を中心実施されており，その中のキャビテーション法は現場への 適用が試みられている。しかしそれ以外の技術は未だ研究開発の 段階である。

石炭層メタンのみを採掘の対象とした場合は, 次の 3 つの項目 を解決する必要がある。

（1）石炭層メタンの包蔵状態 (含埋蔵量) の的確な評価

(2) 坑井掘削技術の開発および坑井システムの設計 


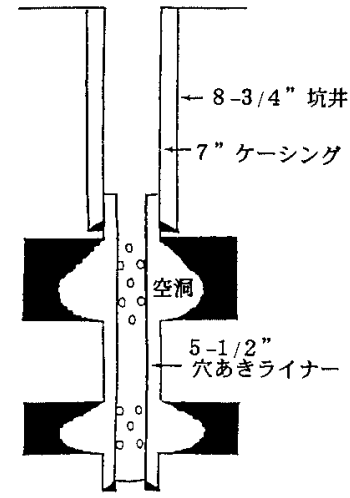

図 15 キャビティー応力除去法による坑井仕上げの例

(3) スティムレーション技術の開発

このうち，(1)および (2) に関しては，日本，特に北海道 の石炭層は米国やオーストラリアの比較的水平な石炭 層に比べて激しい褶曲作用等を受けているため，既存の 探査技術や評価手法および掘削技術等をそのまま適用 することはできない。したがって我が国の石炭層の地質 構造に適応した技術や手法への改良や開発が必要であ る。一方 (3) に関しては，例えば水圧破砕の場合は石炭 層および周辺地層の地質構造 (地圧を含む) 等に大きく 影響を受け，またキャビテーション法の場合は坑井のご く周辺部に限られる等の欠点があり, より革新的なス ティムレーション技術の開発が必要である。

つぎに現在考えられているスティムレーション技術 では必ずしも採掘できない，石炭に化学的に吸着してい る大部分の石炭層メタンの採掘の課題が大きい。この吸 着メタンの採掘方法としては, 石炭への吸着力が強い二 酸化炭素を利用する方法が考えられる。すなわち，石炭 層内に二酸化炭素を送り込み, メタンを化学的に脱着させる方法 である。この方法は(1)石炭層メタンの採掘効率の向上と(2)二酸化 炭素の石炭層内への固定, 処分の両面において, 大きなメリット が期待でき, 米国ではその研究が進められている。また我が国で は平成 12 年度に住友石炭鉱業を中心に JCOAL, 北海道大学, 資 環研北海道センター, 米国エネルギー省等が国際共同研究として 実施している (NEDO 事業)。このプロジェクトの概念を図 17 に 示した。なお，この方法の場合は二酸化炭素が石炭に吸着される ため, 将来同じ石炭層を地下ガス化や地下液化等で採掘する場合 には，二酸化炭素の存在が影響することが考えられる。

しかし一方では，石炭層をメタンの再生工場として利用する発 想もある。これは, 図 17 の石炭層内でメタン生成菌を利用して, 石炭層に固定, 吸着させた二酸化炭素をメタンに変える方法であ る ${ }^{21)}$ 。メタン生成菌に関しては，炭鉱内における自然発火現象の 研究の課程でその存在の可能性が示唆されている ${ }^{22)}$ 。ただし, こ の方法の欠点はメタン生成に要する時間が非常に長いことである。

石炭層メタンの革新的な採掘技術に関しては，石炭層メタンの みを単独で開発する視点からではなく, 個体としての石炭をどの ように採掘し，利用寸るかを超長期的な視点から検討し，その中 で石炭層メタンの採掘，利用について検討すべきである。

\section{6. 石炭層メタンの利用目的}

\section{$6 \cdot 1$ 石炭層メタンの利用目的の現状}

石炭層メタンの成分は基本的には天然ガスと同じである。天然 ガスの国内における利用目的は図 182) のように分類され，また利 用目的ごとの割合は表 $7^{2)}$ の通りである。この表によれば，天然
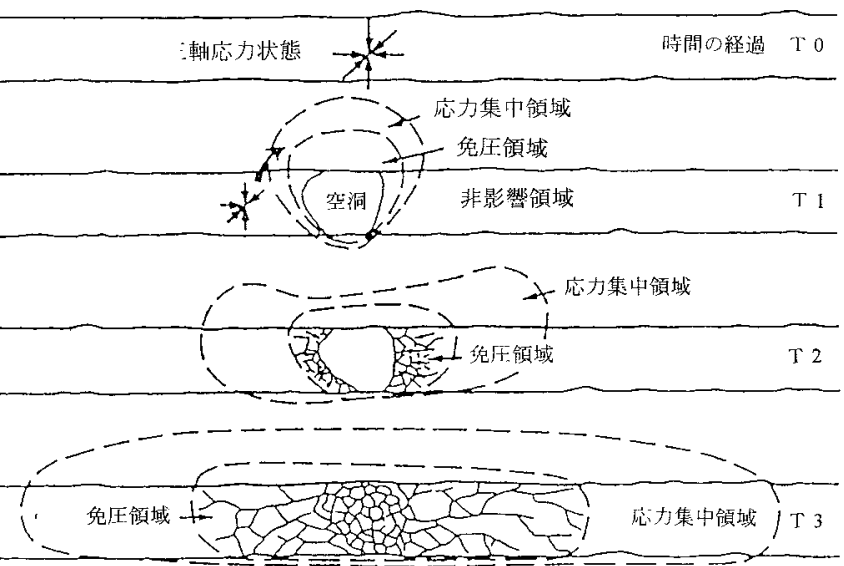

図 16 キャビティー法で作成された空洞周辺炭層・岩盤の変形・応力状態の 経時変化の概念

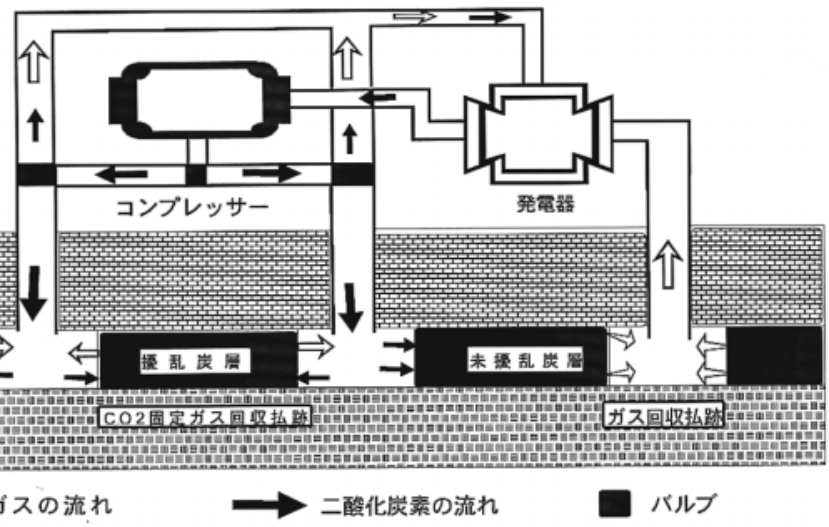

図 17 石炭層メタンの採掘技術と二酸化炭素の石炭層内固定技術に 関する国際共同研究の概念

ガスは都市ガスや発電等のエネルギーの原材料としての利用が主 であったが，1997 年以降は民生用 (都市ガス ) としての利用が 53 \%に増えている。これは発電用の原材料として輸入 LNG の使用 が増えていること, 都市ガスが国内産のカロリーの高い天然ガス に次第に転換されてきていることによるものと思われる。

米国における石炭層メタンの開発は, そもそも国内の天然ガス の埋蔵量への不安が発端になっているといわれている。したがっ て, 石炭層メタンもほぼ全量が天然ガスの既存パイプラインに接 続され，ガス会社に販売されているのが実状である。

オーストラリアの場合もほぼ同様であり, 例えば, Dawson Valley の場合はこの地域から Wallumbila Gladstoneの既存の幹線ガスパイ プラインまで新しいパイプラインを敷設し, 天然ガスの一部とし て販売されている。

中国の場合は表 5 に示したように，ガス抜きガス (メタン濃度 $30 \sim 50 \%)$ の部分が炭鉱地域の家庭用や炭鉱施設用として利用 されている。この場合，ガス抜きによるガスは一度加圧タンクに 貯蔵され，都市ガスのように加圧されて各家庭に送られている場 合もある。ただし，中国全土で利用されているガス抜きガスは前 述のように全量の約 $10 \%$ に過ぎず，今後は大気に放出されてい るガスの回収と利用をいかに進めるかが課題であろう。なお, 1990 年代に入ってから始まった未採掘石炭層からの石炭層メタンの開 発プロジェクトで採掘されたメタンに関しては，その具体的な利 用についての報告はされていない。

日本おける利用概況を表 8 に示した。基本的にはガス抜きした ガス (メタン濃度は炭鉱により異なる ) が自社内の暖房用や発電 用の燃料として利用されているが，都市ガスの一部として販売も 
総説 : 石炭層メタンの採掘技術・利用目的の現状と将来展望

（利用技術上の分類）

(産業別)

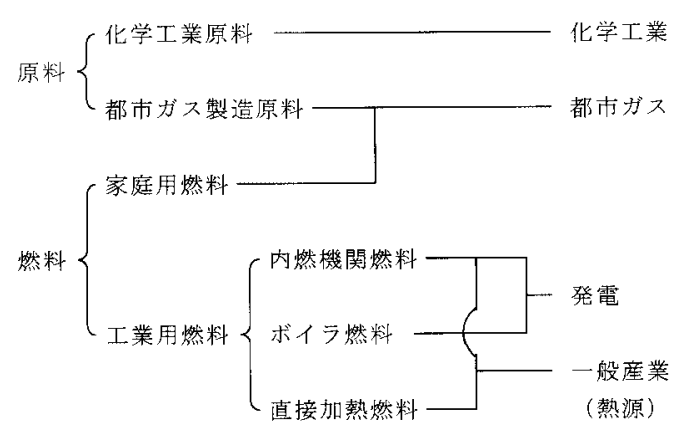

図 18 天然ガスの国内における利用目的の分類

されている。その他にメタノール用の原材料として販売された実 績もある。また三菱大夕張炭鉱の場合はメタノール合成工場を建 設し，抜き取ったガスの大部分をその原材料として利用していた のが，国内における石炭層メタンの利用では特徵的であるといえ る。現在は，太平洋炭鉱がガス抜きガス（メタン濃度約 $40 \%$ ) を 都市ガス会社一販売するとともに, このメタンから DME (ディメ チルエーテル ) を製造するためのパイロットプラント (NEDO 事 業，日産 5 t) による試験を釧路で実施している。

\section{$6 \cdot 2$ 石炭層メタンの新しい利用法}

現在, 国内では約 5,000 万 $\mathrm{t}$ の石炭が発電用に使用されている。 また国内炭は約 370 万 $\mathrm{t}$ の全量が発電用である。一方, 地球環境 の観点から発電用エネルギーの原材料は石油や石炭から原子力や 自然エネルギー, 将来的には熱核融合に転換されることが十分に 予測される。また, 自動車の原動力は電気や燃料電池への変換が 確実に進んできている。これは石油, 天然ガスおよび石炭のエネ ルギー資源としての使命が次第に小さくなるであろうことを示唆 しているといえる。とはいえ, 究極のエネルギーといわれている 熱核融合が実用化されるまでの間は, 石炭および石炭層メタンに 頼らざるを得ないことも事実である。そのため, 我が国では産炭 国から低価格で安定的に長期間輸入するため, 採掘および保安に 係わる技術の協力や移転を行っているが，将来的には石油・天然 ガスの産出国が逆に輸入国になり, 石炭の価格の高騰や供給の不 安定化を招くことは十分に予測される。

つぎに, 現代社会で使用されている各種の工業 (化学) 製品の原 材料には金属, 石油, 天然ガス等が使用されている。しかし, 石 油や天然ガス, 金属鉱物等は有限の資源であり, これらが枯渇し た場合の代替原材料は未だに見つかっていない。また一方では, 石油, 天然ガスおよび外国産石炭の輸入が不安定になってくるこ とも考えられる。このような観点から考えた場合, 純国産である 石炭層メタンおよび石炭が担う役割は大きい。

石炭層メタンの新しい利用方法としては大別して (1) エネル ギーの原材料，(2) 工業 (化学) 製品用の原材料であろう。

まず (1) に関しては, 石炭層メタンを採掘し, 天然ガスパイプ ラインに投入し，比較的安価な燃料として利用している海外，特 に米国と比べた場合，国内では採掘施設の建設や消費地までの運 搬等に要する経費が膨大になり，石炭層メタンを直接燃焼させる 現在の利用方法は経済性上不可能に近い状況にあるといえる。こ のため, 燃料として直接燃焼させる場合には，例えば石炭との混 合燃焼や二酸化炭素の採掘跡への固定・貯蔵との組み合わせ等, より効率的な利用技術の開発が必要である。

一方，利用に際しては石炭層メタンの付加価值を高めることが 重要である。そのためには, 自動車用燃料電池や今後一般家庭に も普及していくであろう燃料電池用の燃料に利用することを目的
表 7 天然ガスの利用目的別の利用割合 (1991)

\begin{tabular}{|c|c|c|c|}
\hline & $\begin{array}{c}\text { 民生用 } \\
\text { (都市ガス) }\end{array}$ & 発電用 & 化学. 業用 \\
\hline 世界全体 & $29 \%$ & $29 \%$ & $42 \%$ \\
\hline 米 国 & $45 \%$ & $16 \%$ & $39 \%$ \\
\hline $\begin{array}{c}\text { 日 本 } \\
\text { (1996 年) }\end{array}$ & $\begin{array}{l}24 \% \\
(53 \%)\end{array}$ & $\begin{array}{r}67 \% \\
(29 \%)\end{array}$ & $\begin{array}{c}9 \% \\
(14 \%)\end{array}$ \\
\hline
\end{tabular}

注 1) 日本の場合、1996年以降は発電用然料にLNGO 使用が增えている。

注2）1996年は 3 つ利用目的以外にその他 $14 \%$ 名西る。

表 8 石炭層メタンの国内における利用概況

\begin{tabular}{|c|c|c|c|}
\hline 年 & 会社 & 利用目的 & 内容 \\
\hline $1935 \sim 1953$ & 新㟪内症鉱 & 燃料 & $\begin{array}{l}\text { 2000kw発電用ボイラー用 } \\
\text { 総ガス量 : } 13500 う j \mathrm{~m}^{3}\end{array}$ \\
\hline $1944 \sim ?$ & 常鄨宸鉱 & 化学製品用原材料 & $\begin{array}{l}\text { ×タ人一心原料として販売 } \\
\text { 暖房术イ万用 } \\
\text { 都市ガス用 }\end{array}$ \\
\hline $1956 \sim ?$ & 日本策䡮 & 化学製品用原材料 & アンモンニア原料として販范 \\
\hline $1959 \sim ?$ & 三菱大夕張岸较 & 化学料製品用原材料 & 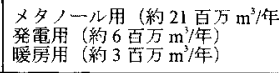 \\
\hline ～現在 & 太平洋岸鉣 & $\begin{array}{l}\text { 燃料 } \\
\text { 化学製品用原材料 }\end{array}$ & 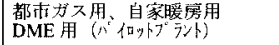 \\
\hline
\end{tabular}

として, メタン濃度の高いガスの生成技術や水素への直接転換技 術の開発, これらの消費地までの安全で安価な運搬技術の開発等, 採掘現場における生産システムや供給システムの構築が重要であ ろう。

次に (2)に関しては, 現在も各種の工業 (化学) 製品用の素材と して利用されているが，金属材料の性質に匹敵する素材，リサイ クルや再資源化が可能な素材, 更には最終処分段階においても環 境への影響がないまたは非常に少ない素材として利用できる技術 の開発等が重要である。

以上の利用の目的や方法は現状の技術の延長線上で達成可能な 部分もあるが，長期的には更に革新的な利用や利用技術の開発が 必要と思われる。

\section{7. あ と がき}

石油, 天然ガスに比べて大量に賦存している石炭に付随してい る石炭層メタンの採掘技術および利用方法の現状を分析し，これ らの長期的な将来展望を示した。これらの概要をまとめると以下 の通りである。

（1）石油, 天然ガスの資源量は有限で, 残存埋蔵量も少なく なってきている。このため, ポスト石油, ポスト天然ガスとして は, 資源量や環境の面から超長期的には熱核融合の実用化が望ま れるが，それまでの間のエネルギーの原材料の確保が重要な課題 である。

（2）原子力や各種の自然エネルギーは工業 (化学) 製品等の原 材料にはなり得ない。

（3）石炭および石炭層メタンは有限ではあるが，石油や天然ガ スに比べてその量が多く, 国内にも大量に賦存する純国産の化石 資源である。

（4）炭層メタンは燃料電池用燃料等や各種工業(化学) 製品等の 原材料等の付加価值の高いものへ転換して利用すべきである。

（5）石炭層メタンは他の非在来型天然ガスに比べて資源量や 採掘技術等の基礎資料が比較的多いとはいえ, 効率的かつ経済的 な採掘および利用を図るためには

(1) 賦存状態および資源量の精密調査

(2) 革新的な採掘・利用技術の研究開発 が重要である。 
（6）（5）を実施することが, 資源の乏しい我が国における資源の 確保と安全を保障することになる。

最後に, 本稿では石炭層メタンに限ってその採掘技術および利 用方法について現状と将来展望を述べたが，米国およびヨーロッ パ連合体 (EU) は地下ガス化技術の開発など, 石炭の革新的な採掘 技術の開発を国家事業として長期間にわたって継続的に行ってい る。一方国内では昭和 $30 \sim 40$ 年代に行ったのみで, 以降は全く 実施されていない。

近い将来の化石資源の枯渇や産出国の輸出制限等などに直面し た場合に備え，米国やヨーロッパ連合体と同様に，石炭および石 炭層メタンの採掘・利用に関わる自前の技術を持つことは百年単 位の超長期的な観点から政府が国家プロジェクトとして真剣に取 り組むべき重要な課題であると考えられ，これらの採掘技術や利 用技術の開発を早急に推進することを提案する。

謝辞本稿の作成に当たっては, 次に掲げる各種の報告書, 論文，文献等を参考，引用，参照させて頂いた。また JCOAL の玉 利彬調查役には貴重なご意見を頂いた。ここに各位に感謝を申し 上げる。

\section{引用文 献}

1) 日経サイエンス社：日経サイエンス, No. 6,p. 19-45,(1998)

2）資源・エネルギー庁監修 : 資源エネルギー年鑑 $(1999-2000)$

3）小川克郎：第 11 回エネルギー総合工学シンポジウム資料, p. 43-45, (1992)

4）財) 石炭エネルギーセンター: 石炭層メタンガスワークショップ資料集, (1998)

5) 藤田和男：資源と素材，Vol. 110, No. 12, p. 919-926,(1994)

6) 浅川 忠: 石油技術協会誌, Vol. 60, No. 2, p. 128-135, (1996)

7) (財) エネルギー総合工学研究所 : 非在来型天然ガスに関寸る調查報告書, p. 255 $-368,(1992)$

8） NEDO：コールベッドメタン資源導入システムの可能性調査，p. 18-72,(1991)

9） NEDO：石炭及び石炭層ガスに係る総合資源評価に関する基礎調查，p. 9-57, (1993)

10) Byrer, C.W. et al. : Proc. of Int. Coalbed Methane Symp., p. 325, (1999)

11） NEDO : コールベッドメタン利用に関する技術開発課題調査, p. 15-88, (1992)

12) Mellett, C.W. : Coal Seam Methane in Australia, 石炭層メタンガスワークショップ 資料集, (1998)

13）財) 石炭技術研究所 : コールベッドメタン, p. 137-214, (1996)

14) Byrer, C.W. et al. : Proc. of Int. Coalbed Methane Symp., p. 1 - 12, (1999)

15) Durucan, S. et al. : Mining Science and Technology, p. 205-216, (1986)

16) Durucan, S. et al. : Proc. of Int. Coalbed Methane Symp., p. 33-49, (1992)

17） (財) 石炭技術研究所 : コールベッドメタン, (1992)

18) Lambert, S. W. et al. : Oil and Gas Journal, p. 87-92,(1989)

19) Schraufnagel, R. A. et al. : Oil and Gas Journal, p. 48-54, (1990)

20) Holditch, S.A. et al. : Final Report of Gas Research Institute, (1987)

21）小出 仁, 他 : 資源 - 素材学会春期大会講演集, p. 222-223, (2000)

22）羽田博憲，他：日本鉱業会誌，Vol. 103, No. 1192, p. 373-376, (1987) 